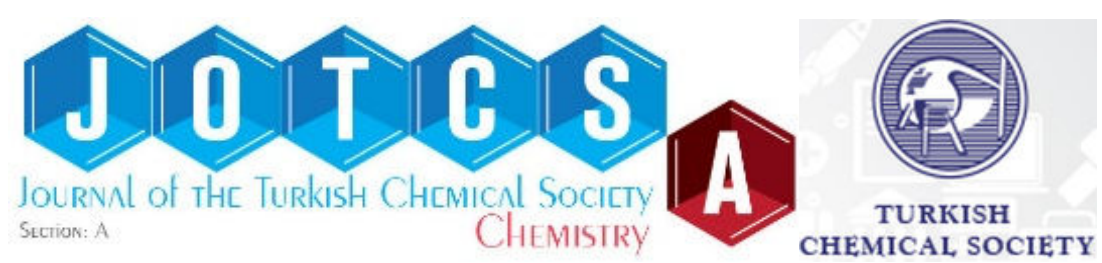

(This article was presented to the 28th National Chemistry Congress and submitted to JOTCSA as a full manuscript)

\title{
Synthesis and Characterization of Cellulose-Based Bio-Polymer Aerogel Isolated from Waste of Blueberry Tree (Vaccinium myrtillus)
}

\author{
Mehmet KAYA* \\ ${ }^{*}$ Recep Tayyip Erdoğan University, Faculty of Arts and Sciences, Department of Chemistry \\ 53100, Rize, Türkiye.
}

\begin{abstract}
Cellulose aerogel (CA) with a highly porous structure is environmentally friendly, thermally stable, and flame retardant. These properties in material worlds have attracted large interest as a potentially industrial material. In this paper, cellulose aerogel with flame retardant feature was produced from pruned branches and bushes of blueberry wastes (PBW). Firstly, cellulose raw material was obtained from these wastes and then, cellulose aerogel was prepared via freeze-drying, followed by cellulose hydrogel production. The work showed that a three dimensional network aerogel structure was prepared from $\mathrm{NaOH} /$ Urea as scaffold solution. The present cellulose aerogel has excellent flame retardant property, which can extinguish within $140 \mathrm{~s}$. By the way, it was inferred that thermal stability performance of cellulose aerogel could be an efficient potential thermal insulating material. Besides, this process is sustainable, easily available at low cost, and suitable for industrial applications.
\end{abstract}

Keywords: Aerogel; Cellulose; Bio-polymer; Blueberry; Hydrogel.

Submitted: June 30, 2016. Revised: August 22, 2016. Accepted: September 02, 2016. Cite This: Kaya M., Synthesis and Characterization of Cellulose-Based Bio-Polymer Aerogel Isolated from Waste of Blueberry Tree (Vaccinium myrtillus). JOTCSA. 2016;4(1):299-310. DOI: $10.18596 /$ jotcsa.57549.

*Corresponding author. E-mail: mehmet.kaya@erdogan.edu.tr. 


\section{INTRODUCTION}

Today, composite materials take an important place in the industrial area due to their variety and advantages (1-3). Some materials are inadequate to meet some physical and/or chemical properties required in the fields of application. When these materials are supported by another type of materials in various amounts, composite structures providing the required properties are obtained, which is a method commonly used nowadays. In recent years, people's interest in polymeric composite originating from cellulose obtained from vegetable wastes has gradually increased because of its gripping properties $(4,5)$. An important reason why cellulose products are preferred is that it provides composite materials with some advantages such as high strength and thermal insulation (6). Being organic substances, cellulosic waste materials also bio-degrade in a short while and they do not have any disadvantages except their unaesthetic effects on the environment. Utilizing cellulosic waste materials and recycling them as new useful composite materials play a crucial role in contributing to the national economy. In addition, it decreases energy costs and consequently provides added value in regions where there are limited energy sources. Recently, aerogels from cellulosic wastes have great interest, because they have their own perfect feature (7). These kind of aerogels, which are among the lightest solid and a new third-generation materials, are one of the finest insulation materials available $(8,9)$. Traditional aerogels are mainly made of silica, which is not environmentally-friendly. In contrast, cellulose is a major component of wood, the most abundant, low cost naturally occurring polymer of glucose and attracts a lot of interest for producing novel aerogel materials. In addition to thin films, sponges and fibers, functional materials with high added value, such as cellulose nanocrystals, nanofibers, hydrogels and aerogels can be made from cellulose (10-13). Cellulose based aerogels have several unique features such as super absorbent and heat insulating. In this regard, when the variety of sources is taken into consideration, it is aimed to use PBW found abundantly in the Eastern Black Sea region, especially in Rize, as an economic value in Turkey. With this study, a new product which is biopolymer, eco-credential, biodegradable, low-cost, and flame-retardant was achieved using cellulose as a raw material obtained from wastes of the pruned blueberry tree, which is one of the important herbal products in the mentioned region. In addition to the structural and thermal characteristics, flame retardation, and surface properties of CA biopolymer materials obtained from the study were determined with the help of the scanning electron microscope (SEM), Fourier transform infrared spectroscopy (FT-IR), thermal analysis (TG-DTG/DTA), X-ray diffraction (XRD), Brunauer-Emmett-Teller (BET) surface area measurement techniques (pore size, volume, type, and surface areas), and flame retardant measurements. 


\section{EXPERIMENTAL SECTION}

\section{Materials}

All chemicals (urea, sodium hydroxide, and ethanol) were of analytical grade and purchased from Merck. All the solutions were prepared with deionized (DI) water. The isolation of cellulose fibers from PBW was performed by a way of an environmental friendly process for cellulose extraction and bleaching .

\section{Cellulose production from PBW}

The PBW was washed with DI water for a few times and filtrated using a cloth strainer to remove impurities such as water soluble sand, soil etc. Alkaline treatment was carried out in $\mathrm{NaOH}$ solution of $4 \mathrm{wt} \%$ at $80^{\circ} \mathrm{C}$ for three times. Alkaline treated fibers were subjected to $\mathrm{NaClO}_{2}$ or $\mathrm{H}_{2} \mathrm{O}_{2}$ bleaching of 1.7 wt\% in acetic acid buffer at $80^{\circ} \mathrm{C}$ for 4 times. The resulting fibers were strained and rinsed with DI water and cloth strainer until it reached neutrality. Afterwards, the PBW sawdust powder was oven-dried at $105^{\circ} \mathrm{C}$.

\section{Acid Treatment}

Bleached PBW product was hydrolyzed in pre-heated $\mathrm{H}_{2} \mathrm{SO}_{4}$ (64 wt\%) (14). The high concentration of acid was removed through centrifugation at $10.000 \mathrm{rpm}$ for $10 \mathrm{~min}$ and repeated until the solution was turbid. The resulting cellulose suspension was filtered using glass filter or cellulose membrane in DI water until the suspension reached a $\mathrm{pH}$ of 5 .

\section{Production of Cellulose Aerogels}

Cellulose fibers ( 2 wt \%) were dispersed into a sodium hydroxide/urea solution (1.9 wt \%/10 wt \%) by sonicating for $6 \mathrm{~min}$. Then the solution was placed in a freezer for more than $24 \mathrm{~h}$ for gelation to take place. After the solution had been frozen, it was then thawed at room temperature, followed by immersion into ethanol (99 vol \%) for coagulation ( $3 \mathrm{~h}$ ). The specimen's thickness was controlled around $1 \mathrm{~cm}$ with a diameter of $3.8 \mathrm{~cm}$ using a beaker as a mold. After coagulation, solvent exchange was carried out by immersing the gel in DI water for 2 days. Freeze-drying was carried out for the sample for 2 days at $-98{ }^{\circ} \mathrm{C}$ with a freezedryer after pre-freezing the sample at $-18{ }^{\circ} \mathrm{C}$ for $12 \mathrm{~h}(15)$.

\section{RESULTS and DISCUSSIONS}

\section{SEM Analysis}

The structural and morphological characteristics of CA were displayed by SEM and are shown in Figures 1-3. It is clear that the CA has a largely homogeneous porous structure consisting of microfibrillar networks (Figure 3). The pore structure results from the sublimation of frozen 
water during the freeze-drying process (16). This property is coherent with those of nitrogen adsorption data, and seems to be reasoned by crystal formation during the relatively slow freezing process, which would have caused to press out fibrils to form the film-like structure (17). According to the aforesaid findings, the CA with a homogeneous microporous structure can be fabricated via in situ templated synthesis of sample in the cellulose gel framework (16).

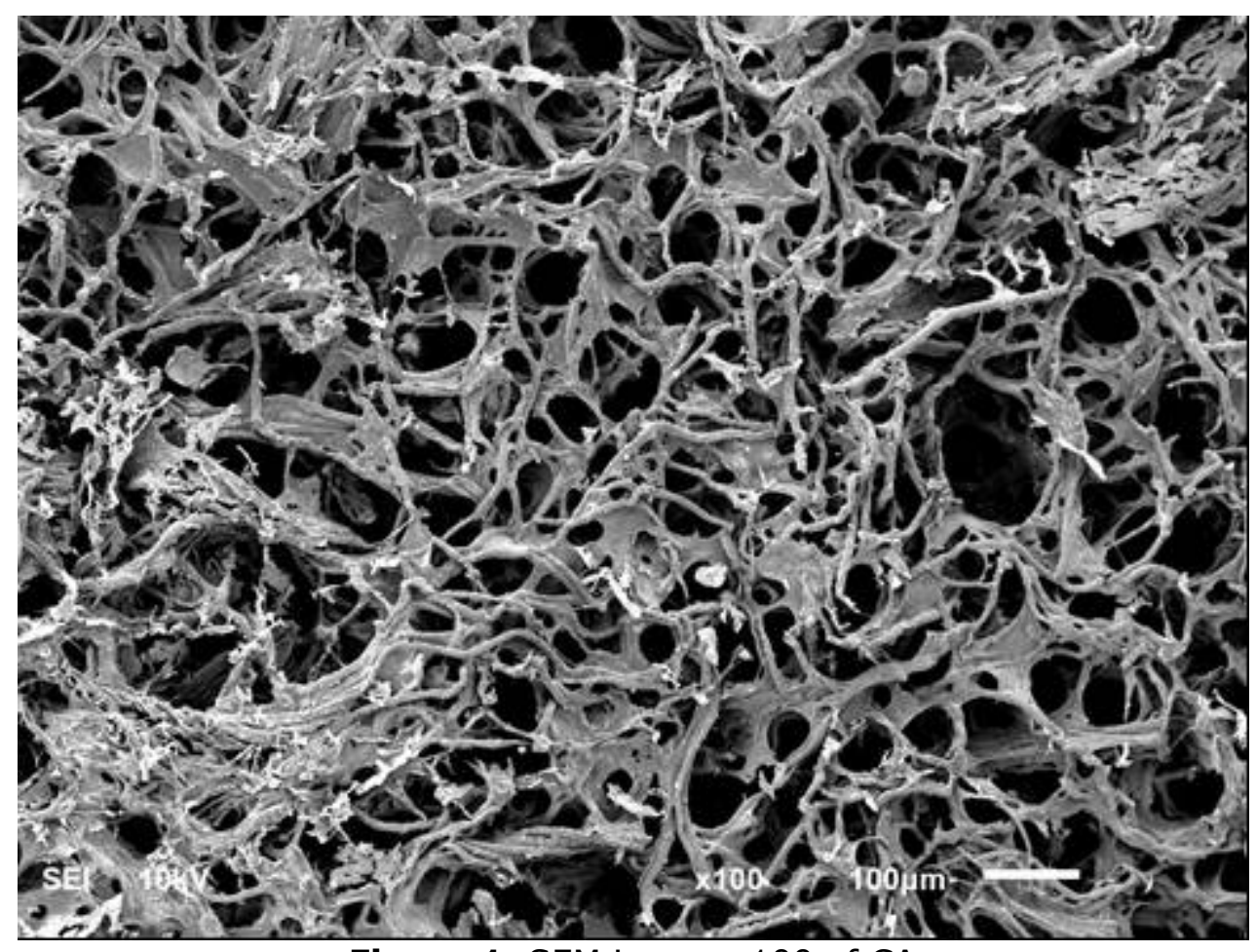

Figure 1. SEM image $\times 100$ of CA 


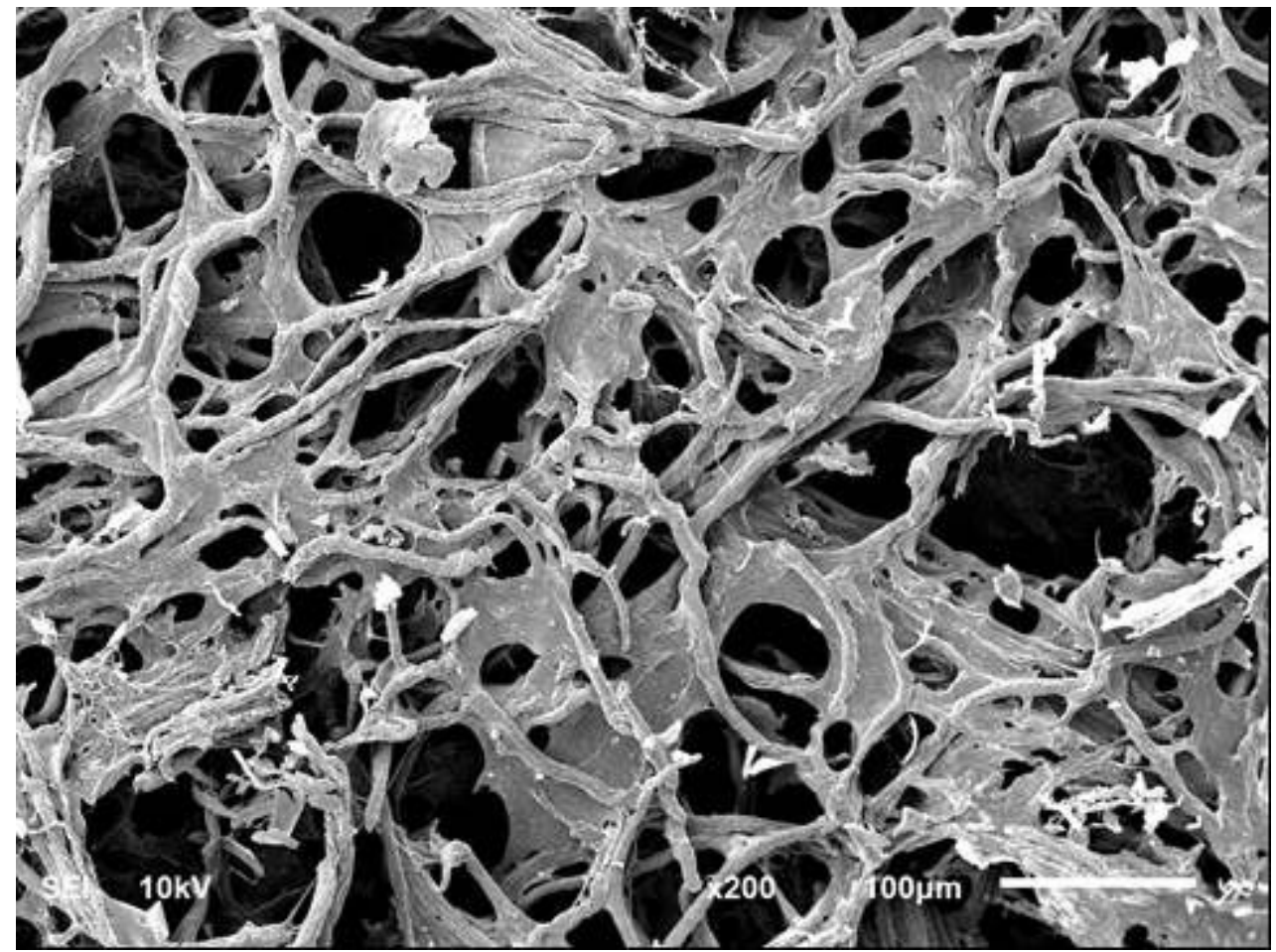

Figure 2. SEM image $\times 200$ of CA.

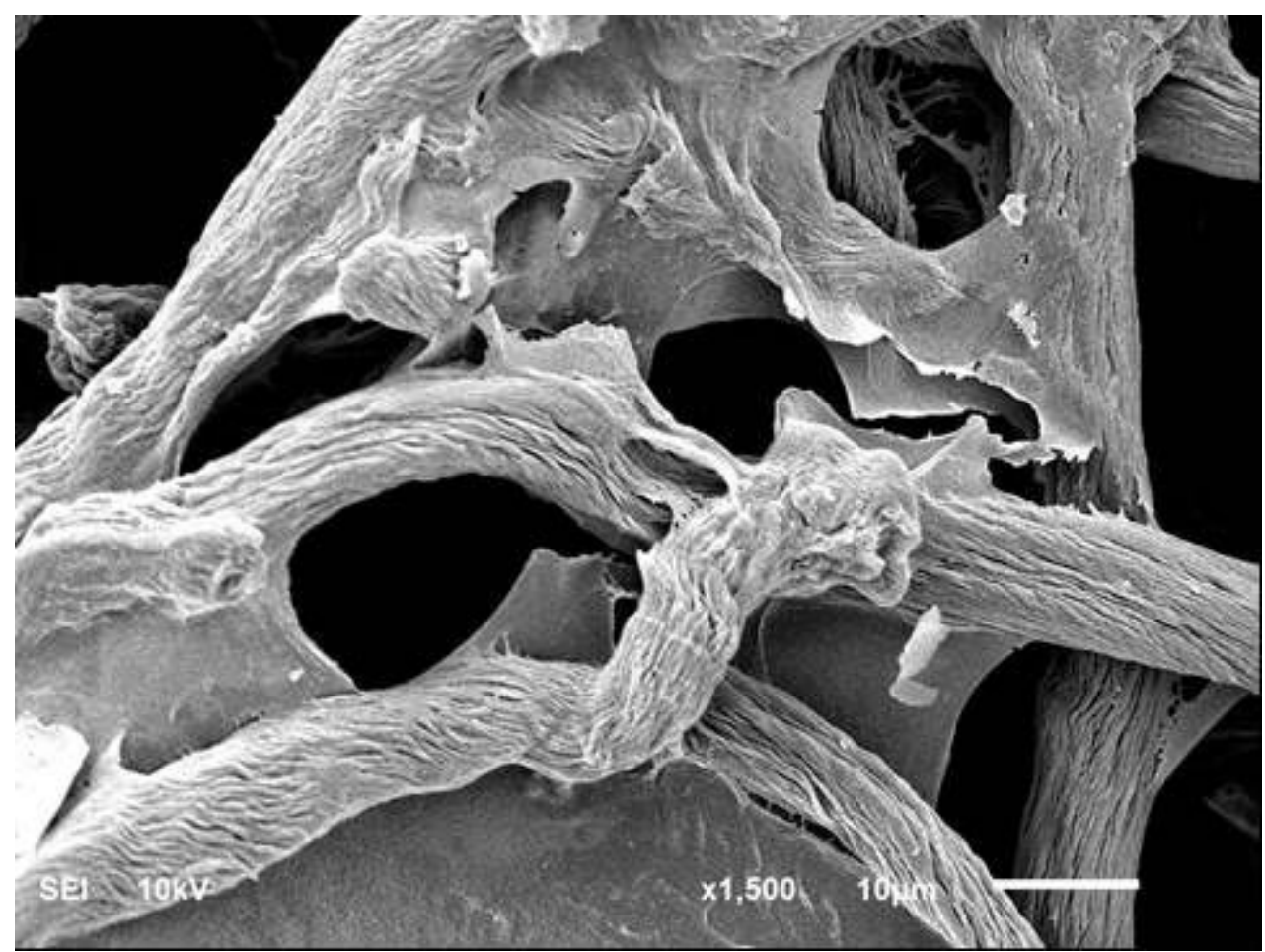

Figure. 3. SEM image $\times 1500$ of CA.

\section{FT-IR Analysis}

The FT-IR signal pertaining to the characteristic functional groups are shown in Figure 4. It can be observed that the several components of the CA are most likely consisted of alkene, esters, aromatics, ketone and alcohol, with different oxygen-containing functional groups observed, 
e.g., $\mathrm{OH}\left(3450-3300 \mathrm{~cm}^{-1}\right), \mathrm{C}=\mathrm{O}\left(1775-11680 \mathrm{~cm}^{-1}\right), \mathrm{C}-\mathrm{O}-\mathrm{C}\left(1162 \mathrm{~cm}^{-1}\right)$, and $\mathrm{C}-\mathrm{O}-(\mathrm{H})(1050$ $\left.\mathrm{cm}^{-1}\right)(18)$.

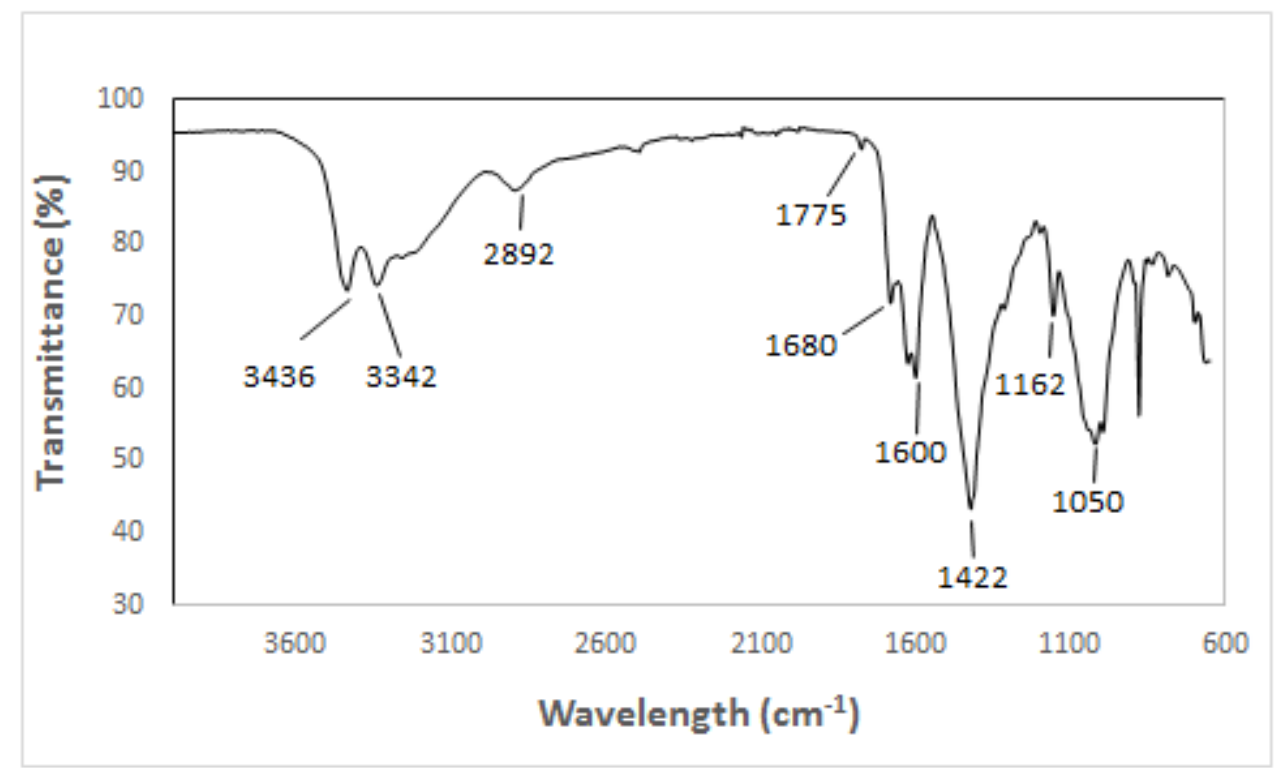

Figure 4. FT-IR Spectrum of CA.

\section{Thermal Analysis}

Considering industrial applications of heat insulating materials, the thermal behavior of the CA was investigated by TGA analysis. As demonstrated in Figure 5, a gradual weight loss occurs up to about 500 degrees. The weight loss at a temperature range of $0^{\circ} \mathrm{C}-200^{\circ} \mathrm{C}$ can be attributed the loss of moisture in both surface and inner moisture evaporation in porous structure where removal of water is more difficult relatively (18). The stage of weight loss around $300-500{ }^{\circ} \mathrm{C}$ can be ascribed to the depolymerization of cellulose with generation of $\mathrm{CO}_{2}$ and volatile hydrocarbons (16). Finally, it appeared that the CA has high thermal stability (weight loss only $60 \%$ at about $350^{\circ} \mathrm{C}$ ).

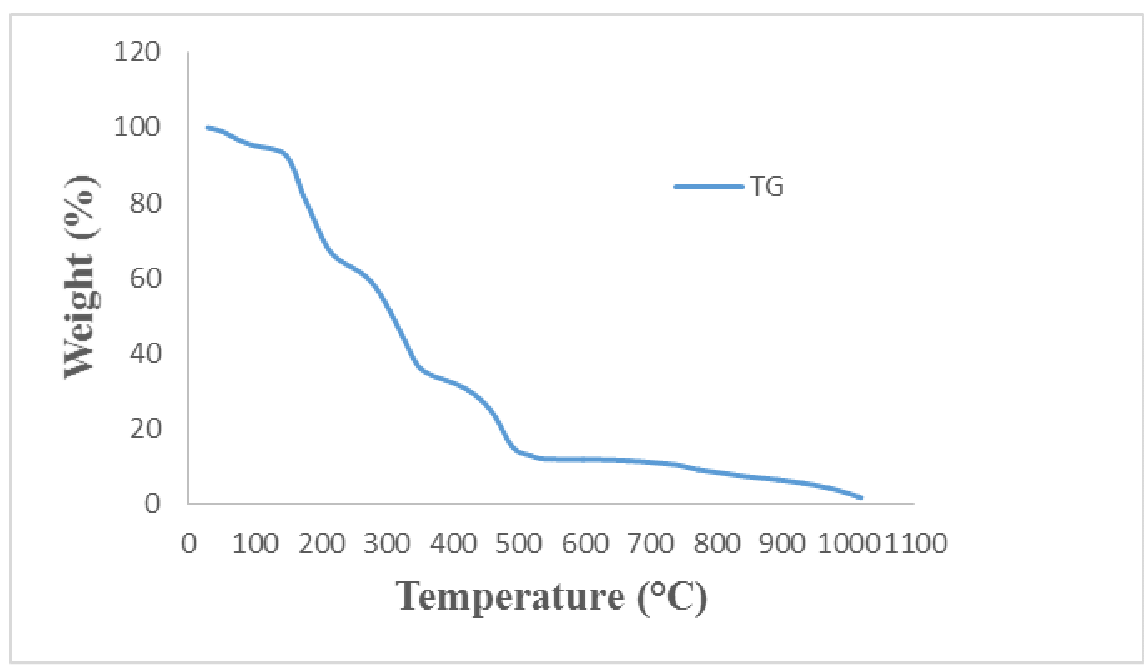

Figure 5. Thermal Stability of CA. 


\section{XRD Analysis}

XRD spectrum for CA was performed on a Rigaku DMAX-3C automated diffractometer using $\mathrm{Ni}$ filtered CuK-beta radiation ( $40 \mathrm{kV}$ and $30 \mathrm{~mA}$ ). Diffractograms were recorded from $5^{\circ}$ to $40^{\circ}$ at a scan rate of $3 \% \mathrm{~min}$. Figure 6 displayed a crystal structure of cellulose with typical diffraction peaks for the plane $(200)$ at $2 \theta=22.20^{\circ}$ and $(110)$ at $2 \theta=19.8^{\circ}$. Crystallinity index (CrI) was calculated from the intensity of the 200 peak $\left(\mathrm{I}_{200}, 2 \theta=22.2^{\circ}\right)$ and the intensity minimum between 200 and $110\left(\operatorname{Iam}, 2 \theta=19.8^{\circ}\right)$ peaks using the empirical equation ( 8 ):

$$
\operatorname{CrI}=\left\{\left(\mathrm{I}_{200}-\mathrm{I}_{\mathrm{am}}\right) / \mathrm{I}_{200} \mathrm{~S} \times 100=76.52 \%\right.
$$

It was observed that the cellulose aerogel had a higher crystallinity $(76.52 \%)$ than that of the raw amorphous woody material, probably because of the remotion of hemicellulose and lignin. This result also reveals that amorphous and crystalline cellulose regions are considerably divided.

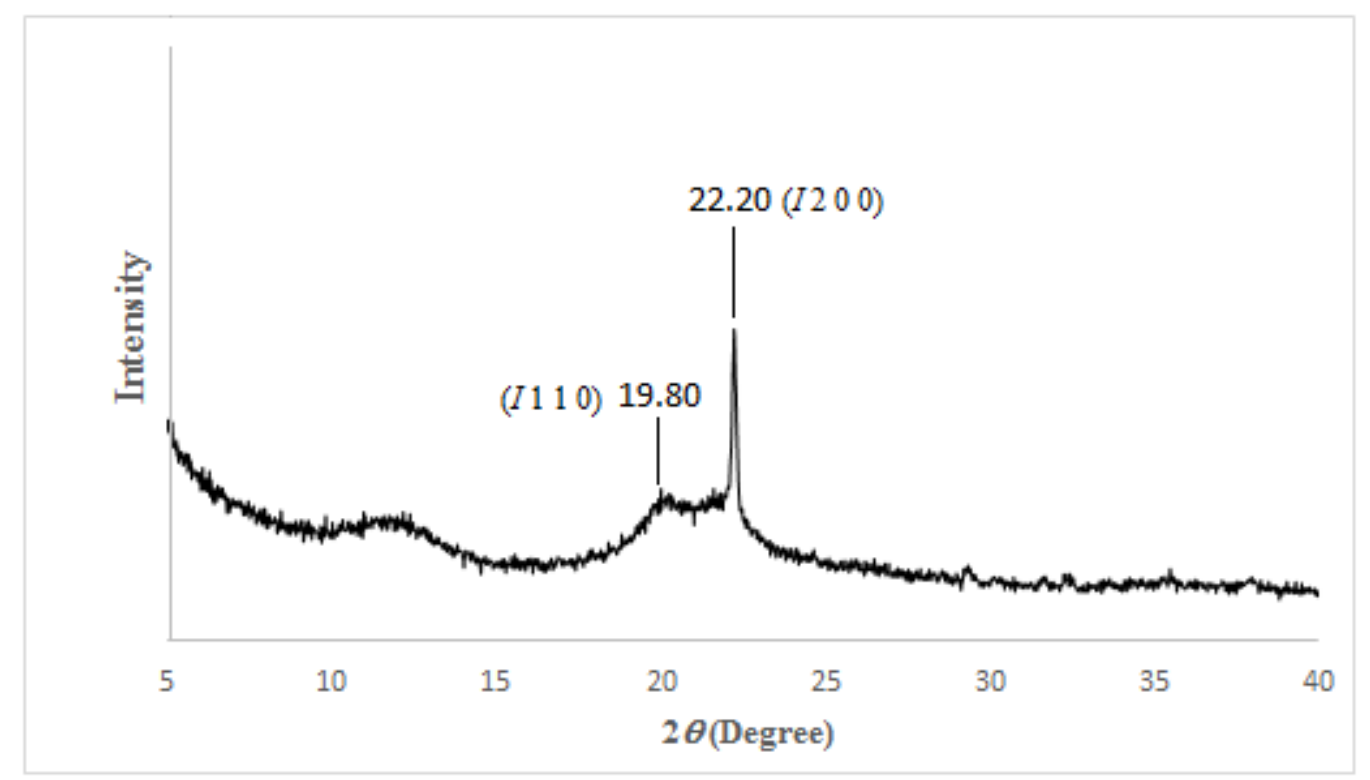

Figure 6. XRD Spectrum of CA.

\section{BET Specific Surface Area}

The pore features of the CA involving the total pore volume, average pore diameter, and specific surface area (from $\mathrm{N}_{2}$ adsorption measurements) are shown in Table 1 . The results showed the CA with the total pore volume and average pore diameter as $0.25 \mathrm{~cm}^{3} / \mathrm{g}$ and 4.30 $\mathrm{nm}$, respectively. The nitrogen adsorption at $77 \mathrm{~K}$ on $\mathrm{CA}$ resembles the type II isotherms (according to IUPAC classification), which are typical for physical adsorption on microporous and non-porous or macroporous solids (Figure 7). The characteristic features of these isotherms are the reversible part at relatively lower pressures and the hysteresis loop at relatively higher pressures (19). To examine the porous structure of the aerogel, nitrogen 
adsorption and desorption isotherm techniques were performed. Figure 7 exhibits the adsorption and desorption isotherms, which show a hysteresis typical of a porous system. According to BET analysis, a specific surface area of $42.25 \mathrm{~m}^{2} \mathrm{~g}^{-1}$ is recorded for the CA.

Table 1. Specific Surface Area and Porosity.

\begin{tabular}{cccc}
\hline Sample & $\begin{array}{c}\text { Specific surface area } \\
\left(\mathbf{m}^{\mathbf{2}} \mathbf{g}^{-1}\right)\end{array}$ & $\begin{array}{c}\text { Average pore } \\
\text { diameter } \\
(\mathbf{n m})\end{array}$ & $\begin{array}{c}\text { Total pore volume } \\
\left(\mathbf{c m}^{\mathbf{3}} / \mathbf{g}^{-1}\right)\end{array}$ \\
\hline $\mathrm{CA}$ & 42.25 & 4.30 & 0.25 \\
\hline
\end{tabular}

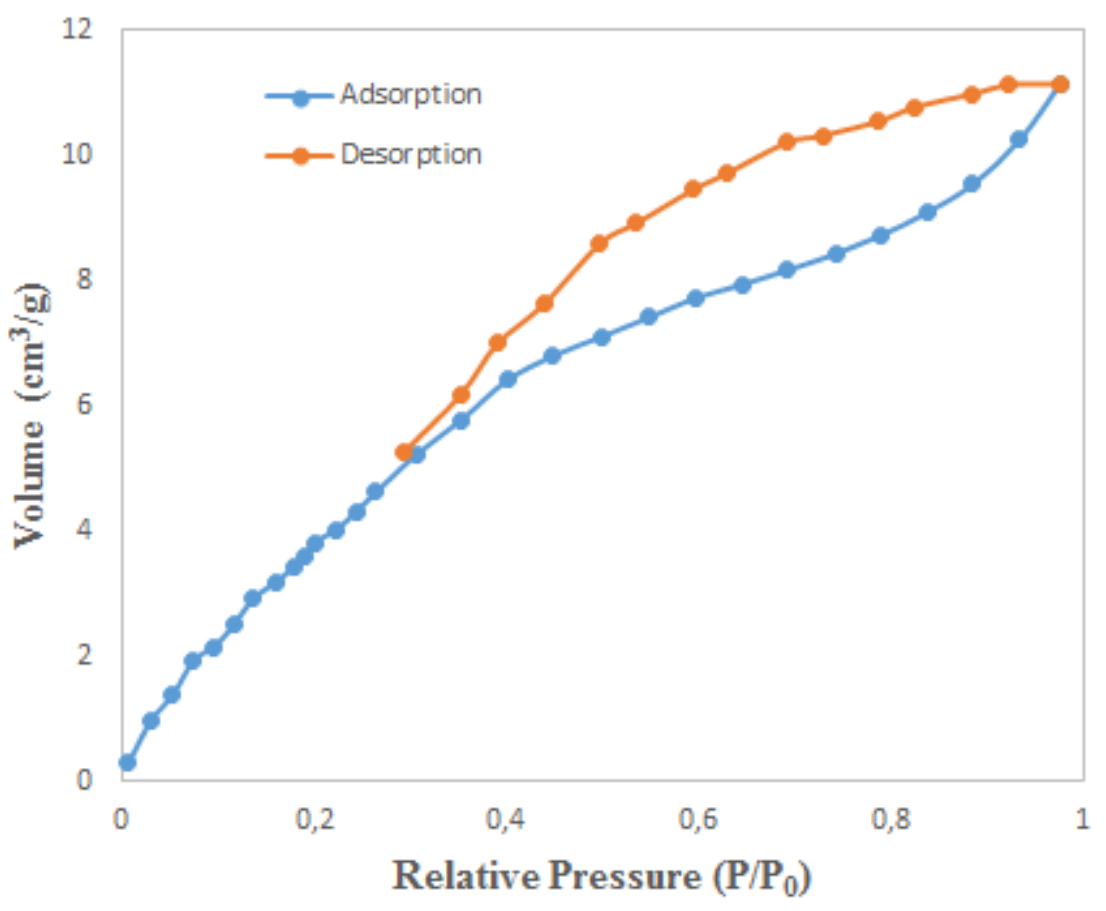

Figure 7. Nitrogen Adsorption-Desorption Isotherm.

\section{Flame Retardant Characteristic of CA}

Due to the investigation, the flame retardant performance of the CA produced in this work, the aerogel was emblazed and the burning velocity was calculated. At this stage, it was observed that the CA was ignited slowly, and burned only the part of 25 percent burned after $33 \mathrm{~s}$ of combustion (see the video in Supporting Information). However, the neat cellulose aerogel was quickly ignited (about $10 \mathrm{~s}$ ) and burned completely after $10 \mathrm{~s}$ of combustion in the literature (16). The photo in Figure 8 demonstrates the remains of the CA after 34 . The combustion velocity of the aerogel decreases from 4 to $3.71 \mathrm{~mm} \mathrm{~s}^{-1}$ (Figure 8 ). Besides, when the CA with the length of $40 \mathrm{~mm}$ was ignited, flame propagation apparently slowed, and then the flame gradually became smaller and finally extinguished within about $140 \mathrm{~s}$. The results indicate that the CA is a highly an efficient flame retardant. 


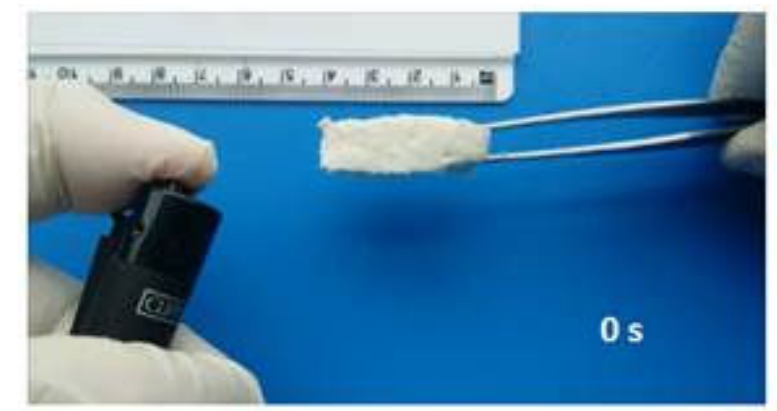

Before

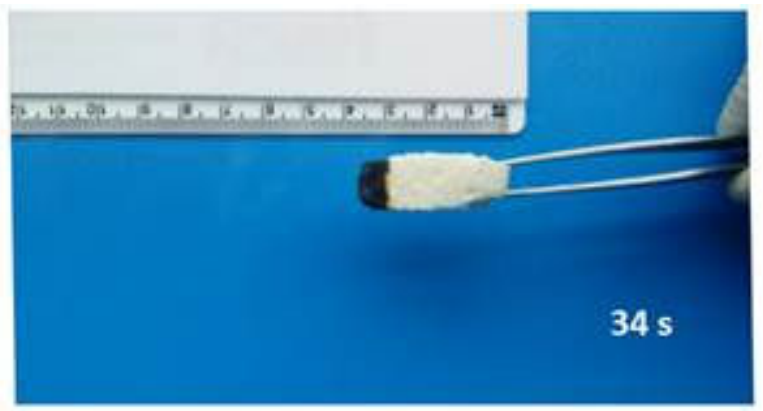

After

Figure 8. Flame Retardant Study.

\section{CONCLUSIONS}

The cellulose aerogel with a highy porous structure was produced from pruned branches and bushes of blueberries via in situ converting cellulose hydrogel scaffold to aerogel. This work is an efficient, environmentally friendly, and low cost process and the bio-polymer material is an effective flame retardant, porous, and potential super absorbent (next studies). It was concluded that the prepared cellulose aerogel has extremely porous networks and perfect flame retardant performance. Besides, the cellulose aerogel has good crystallinity feature and thermal stability. This environmentally friendly and low cost work will offer insight into the new opportunities for the use of inexpensive waste-derived cellulose to fabricate several materials. It has a major potential application in the future of "green" materials chemistry and it may be appropriate for industrial scale production.

\section{REFERENCES}

1. Nishino T, Matsuda I, Hirao K. All-cellulose composite. Macromolecules. 2004;37(20):7683-7.

2. Dormanns JW, Schuermann J, Mussig J, Duchemin BJC, Staiger MP. Solvent infusion processing of allcellulose composite laminates using an aqueous $\mathrm{NaOH} /$ urea solvent system. Compos Part a-Appl S. $2016 ; 82: 130-40$.

3. Yang J, Zhang EW, Li XF, Zhang YT, Qu J, Yu ZZ. Cellulose/graphene aerogel supported phase change composites with high thermal conductivity and good shape stability for thermal energy storage. Carbon. 2016;98:50-7.

4. Ahmadi M, Madadlou A, Sabouri AA. Isolation of micro- and nano-crystalline cellulose particles and fabrication of crystalline particles-loaded whey protein cold-set gel. Food Chem. 2015;174:97103.

5. Awal A, Sain M, Chowdhury M. Preparation of cellulose-based nano-composite fibers by electrospinning and understanding the effect of processing parameters. Compos Part B-Eng. 2011;42(5):1220-5.

6. Duong HM, Nguyen ST. Nanocellulose aerogels as thermal insulation materials. In: Pacheco Torgal F, Buratti C, Kalaiselvam S, Granqvist C-G, Ivanov V, editors. Nano and Biotech Based Materials for Energy Building Efficiency. Cham: Springer International Publishing; 2016. p. 411-27. 
7. Postek MT, Vladar A, Dagata J, Farkas N, Ming B, Wagner R, et al. Development of the metrology and imaging of cellulose nanocrystals. Meas Sci Technol. 2011;22(2).

8. Seantier B, Bendahou D, Bendahou A, Grohens Y, Kaddami H. Multi-scale cellulose based new bioaerogel composites with thermal super-insulating and tunable mechanical properties. Carbohyd Polym. 2016;138:335-48.

9. Kobayashi Y, Saito T, Isogai A. Aerogels with 3D ordered nanofiber skeletons of liquid-crystalline nanocellulose derivatives as tough and transparent insulators. Angew Chem Int Edit. 2014;53(39):10394-7.

10. Liu J, Cheng F, Grenman H, Spoljaric S, Seppala J, Eriksson JE, et al. Development of nanocellulose scaffolds with tunable structures to support 3D cell culture. Carbohyd Polym. 2016;148:259-71.

11. Shen XP, Shamshina JL, Berton P, Bandomir J, Wang H, Gurau G, et al. Comparison of hydrogels prepared with ionic-liquid-isolated vs commercial chitin and cellulose. Acs Sustain Chem Eng. 2016;4(2):471-80.

12. Kwon GJ, Kim DY, Hwang JH, Kang JH. Structural properties and adsorption capacity of holocellulose aerogels synthesized from an alkali hydroxide-urea solution. J Korean Phys Soc. 2014;64(10):1470-3.

13. Wang ZG, Liu SL, Matsumoto Y, Kuga S. Cellulose gel and aerogel from LiCl/DMSO solution. Cellulose. $2012 ; 19(2): 393-9$.

14. Beck-Candanedo S, Roman M, Gray DG. Effect of reaction conditions on the properties and behavior of wood cellulose nanocrystal suspensions. Biomacromolecules. 2005;6(2):1048-54.

15. Nguyen ST, Feng JD, Le NT, Le ATT, Hoang N, Tan VBC, et al. Cellulose aerogel from paper waste for crude oil spill cleaning. Ind Eng Chem Res. 2013;52(51):18386-91.

16. Han YY, Zhang XX, Wu XD, Lu CH. Flame Retardant, Heat insulating cellulose aerogels from waste cotton fabrics by in situ formation of magnesium hydroxide nanoparticles in cellulose gel nanostructures. Acs Sustain Chem Eng. 2015;3(8):1853-9.

17. Jin H, Nishiyama Y, Wada M, Kuga S. Nanofibrillar cellulose aerogels. Colloid Surface A. 2004;240(13):63-7.

18. Poletto M, Ornaghi HL, Zattera AJ. Native Cellulose: structure, characterization and thermal properties. Materials. 2014;7(9):6105-19.

19. Zhang SQ, Wang J, Shen J, Deng ZS, Lai ZQ, Zhou B, et al. The investigation of the adsorption character of carbon aerogels. Nanostruct Mater. 1999;11(3):375-81. 
Türkçe Öz ve Anahtar Kelimeler

\title{
Yabanmersini Ağacı Atıklarından (Vaccinium myrtillus) Selüloz Esaslı Biyo-Polimer Aerojelinin Sentezi ve Karakterizasyonu
}

\author{
Mehmet KAYA
}

\begin{abstract}
Öz: Selüloz aerojeli (CA) çok gözenekli bir yapıya sahiptir ve çevreyle dosttur, ısıl olarak kararlıdır ve alev geciktirici özelliği vardır. Malzeme dünyasında bu özellikler çok ilgi çekmekte olup potansiyel olarak endüstriyel bir malzeme çıkmasına da yol açabilir. Bu çalışmada, alev geciktirici özelliğine sahip selüloz aerojeli, yabanmersini ağacı atıklarından budanmış dal ve çalılarından üretilmiştir. Öncelikle selüloz ham maddesi elde edilmiş ve daha sonra selüloz hidrojel üretilmiştir. Ardından dondurarak kurutma ile selüloz aerojel oluşturulmuştur.

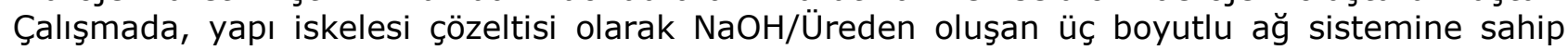
aerojelin üretilmesi anlatılmıştır. Elde edilen selüloz aerojelin mükemmel alev geciktirici özelliği bulunmaktadır ve 140 saniye içinde sönüm sağlanmaktadır. Bunun dışında, selüloz aerojelin ısıl kararlılık özelliğinin mükemmel bir ısıl yalıtkan olabileceği düşünülmektedir. Son olarak, süreç sürdürülebilir özelliğe sahiptir, düşük maliyetle kolaylıkla elde edilebilir ve endüstriyel uygulamalar için uygundur.
\end{abstract}

Anahtar kelimeler: Aerojel; Selüloz; Biyo-polimer; Yaban mersini; Hidrojel. Sunulma: 30 Haziran 2016. Düzeltme: 22 Ağustos 2016. Kabul: 02 Eylül 2016. 
